\title{
EVALUASI MODEL DISCREPANCY: SALAH SATU MODEL EVALUASI PROGRAM KONSELING
}

\section{Wahyu Nanda Eka Saputra ${ }^{1}$}

\begin{abstract}
Abstrak
Konseling adalah menjadi komponen utama dalam layanan bimbingan dan konseling. Pentingnya program konseling ini, tentunya membutuhkan satu usaha untuk menilai keberhasilan program konseling. Salah satunya adalah dengan melaksanakan evaluasi. Tipe evaluasi yang bisa digunakan adalah evaluasi dengan model discrepancy. Penelitian ini menggunakan desain studi kepustakaan. Penelitian ini menyajikan gagasan ilmiah mengenai model evaluasi program, yaitu model discrepancy melalui sumber data sekunder, seperti jurnal dan buku. Hasil studi kepustakaan menyimpulkan bahwa tujuan dari evaluasi model discrepancy adalah mendeskripsikan kesenjangan antara realita kinerja konselor profesional dalam mengimplementasikan program bimbingan dan konseling di sekolah dengan standar. Selain itu, juga berorientasi pada suatu keputusan untuk membantu konselor dalam mengambil keputusan program konseling. Penelitian ini akan mendeskripsikan evaluasi model discrepancy untuk melihat kesenjangan performa program konseling dengan standar yang ditentukan.
\end{abstract}

Kata Kunci: evaluasi, model discrepancy, konseling

\begin{abstract}
Counseling is a major component in counseling and guidance services. The importance of this counseling program, of course, requires an effort to assess the success of the counseling program. One way is to carry out evaluations. The type of evaluation that can be used is evaluation with the discrepancy model. This paper uses library design studies. This paper presents scientific ideas about program evaluation models, namely the discrepancy model through secondary data sources, such as journals and books. The results of the literature study concluded that the purpose of the discrepancy model evaluation was to describe the gap between the reality of the performance of professional counselors in implementing standardized guidance and counseling programs in schools. In addition, it is also oriented towards a decision to help counselors in making decisions on counseling programs. This paper will describe the evaluation of the discrepancy model to see the gap in the performance of the counseling program to the prescribed standards.

Keywords: evaluation, discrepancy model, counseling
\end{abstract}

\section{PENDAHULUAN}

Konseling adalah jantung hatinya program bimbingan dan konseling di sekolah. Konseling adalah upaya membantu individu melalui proses interaksi yang bersifat pribadi antara konselor dan konseli agar konseli mampu memahami diri dan lingkungannya, membuat keputusan, dan menentukan tujuan berdasarkan nilai

\footnotetext{
${ }^{1}$ Universitas Ahmad Dahlan, wahyu.saputra@bk.uad.ac.id
} 
yang diyakininya sehingga konseli merasa bahagia dan efektif perilakunya (Shertzer \& Stone, 1981). Hal ini jelas bahwa konseling adalah salah satu program yang perlu diimplementasikan dengan baik.

Konseling pada dasarnya juga didefinisikan sebagai helping relationship (Shertzer \& Stone, 1981). Dalam membentuk sebuah helping relationship yang baik dengan dan konseli, konselor harus memiliki atribut pribadi konselor profesional. Tiga atribut pribadi konselor profesional, yaitu (1) kongruen; (2) penghargaan positif tak bersyarat; dan (3) pemahaman empatik yang akurat. Ketiga atribut pribadi konselor tersebut sangat berpengaruh terhadap terjadinya hubungan antara konselor dan konseli yang memiliki peran sangat besar terhadap terjadinya perubahan pada diri konseli (C. R. Rogers, 1995; Carl R Rogers, 1957, 1975) .

Terjadi banyak permasalahan terkait terkait implementasi program konseling. Beberapa penelitian menemukan konselor belum bisa melaksanakan program konseling seperti yang diharapkan. Penelitian dilakukan Juntika tahun 1993 menemukan pelaksanaan program konseling oleh konselor belum sesuai dengan yang diharapkan, yakni masih kurangnya kemampuan konselor menangani dan menggali masalah siswa (Akhmadi, 2014). Penelitian Marjohan tahun 1994 menemukan $39,47 \%$ konselor dapat menerapkan kemampuan profesional konseling dalam kategori tinggi, sedangkan $60,53 \%$ mampu menerapkan kemampuan tersebut pada kategori sedang (Akhmadi, 2014).

Perlu usaha untuk menilai keberhasilan layanan konseling. Salah satunya adalah dengan menerapkan evaluasi dengan model discrepancy. Evaluasi model discrepancy ini dikembangkan oleh Malcom Provus (McKenna, 1981). Provus menjelaskan evaluasi model discrepancy bertujuan untuk mengetahui antara tingkat kesesuaian antara standar yang telah ditentukan dengan penampilan aktual dari pelaksanaan program. Evaluasi sebagai proses manajemen informasi secara berkelanjutan yang mencakup (1) kesepakatan tentang standar-standar tertentu; (2) menentukan ada/tidaknya kesenjangan yang muncul antara performansi dan sejumlah aspek program dengan perangkat standar untuk performansi tersebut; dan (3) menggunakan informasi tentang kesenjangan dalam memutuskan untuk mengembangkan atau melanjutkan atau menghentikan program keseluruhan atau salah satu aspek dari program tersebut (Fitzpatrick, Sanders, \& Worthen, 2004). Terdapat beberapa alasan melaksanakan evaluasi program konseling dengan menggunakan evaluasi model discrepancy. Alasan yang pertama adalah evaluasi model discrepancy ini mudah dilaksanakan karena evaluasi model discrepancy menggunakan prosedur yang sederhana. Alasan lain menggunakan evaluasi model discrepancy adalah waktu dan biaya yang relatif lebih sedikit daripada menggunakan model evaluasi lain, misalnya CIPP. Penelitian ini akan memaparkan konsep evaluasi dengan model discrepancy sehingga diharapkan dapat membantu konselor untuk memberikan panduan melaksanakan evaluasi dengan model discrepancy.

\section{METODE PENELITIAN}

Penelitian ini menggunakan desain studi kepustakaan. Penelitian ini menyajikan gagasan ilmiah mengenai model evaluasi 
program, yaitu model discrepancy melalui sumber data sekunder, seperti jurnal dan buku. Data yang dikumpulkan berupa data teks dari jurnal dan buku yang relevan dengan variabel yang dibahas dalam Penelitian ini. Penelitian ini juga menggunakan analisis konten yang dilakukan dengan menghubungkan, membandingkan, menafsirkan dan menyimpulkan konten dari berbagai teks data yang digunakan.

\section{HASIL PENELITIAN}

Hasil dari kajian teori dan penelitian terdahulu menunjukkan bahwa evaluasi program konseling menjadi salah satu kegiatan penting dalam pelayanan konseling. Hal ini untuk menunjang keberhasilan dari program konseling itu sendiri. Salah satu model evaluasi yang digunakan adalah model discrepancy atau kesenjangan.

Beberapa ahli mendefinisikan pengertian evaluasi program. Bryant dan White menyatakan evaluasi adalah upaya melakukan penilaian tentang apa yang terjadi (Arikunto, 2009). Senada dengan pendapat sebelumnya, Anderson memandang evaluasi sebagai sebuah proses menentukan hasil yang telah dicapai beberapa kegiatan yang direncanakan untuk mendukung tercapainya tujuan (Arikunto, 2009). Sedangkan Tyler pada tahun 1950 mendefinisikan evaluasi program adalah proses untuk mengetahui apakah tujuan program sudah dapat terealisasi (Arikunto, 2009).

Dari berbagai definisi tersebut di atas, dapat diintisarikan bahwa yang dimaksud dengan evaluasi program adalah kegiatan untuk mengumpulkan informasi tentang bekerjanya sesuatu program, yang selanjutnya informasi tersebut digunakan untuk menentukan alternatif atau pilihan yang tepat dalam mengambil sebuah keputusan.

Evaluasi program memiliki beberapa tujuan. Evaluasi program dilakukan dengan tujuan untuk menunjukkan sumbangan program terhadap pencapaian tujuan organisasi (Sudjana, 2006). Selanjutnya, evaluasi program dilaksanakan untuk mengetahui seberapa tinggi mutu atau kondisi sesuatu sebagai hasil pelaksanaan program, setelah data yang terkumpul dibandingkan dengan kriteria atau standar tertentu .

Dengan adanya uraian di atas, dapat dikatakan bahwa evaluasi program merupakan penelitian evaluatif. Penelitian evaluatif dimaksudkan untuk mengetahui akhir dari adanya kebijakan, dalam rangka menentukan rekomendasi atas kebijakan yang lalu, yang pada tujuan akhirnya adalah menentukan kebijakan selanjutnya. Evaluasi model descrepancy dikembangkan oleh Malcolm Provus untuk melihat tingkat kesenjangan yang terjadi di lapangan.

Konseling sebagai hubungan yang berupa bantuan satu-satu yang berfokus kepada pertumbuhan dan penyesuaian pribadi dan memenuhi kebutuhan akan penyelesaian problem dan kebutuhan pengambilan keputusan (Mitchell \& Gibson, 2011). Selanjutnya, dijelaskan juga arti konseling, yang merupakan proses pemberian bantuan melalui wawancara konseling oleh seorang ahli (konselor) kepada individu yang sedang menjalani sesuatu masalah (konseli) yang bermuara pada teratasinya masalah yang dihadapi oleh konseli (Prayitno \& Amti, 2004). Ahli selanjutnya mendefinisikan konseling adalah upaya bantuan yang diberikan seorang pembimbing terlatih dan berpengalaman, terdapat individu-individu yang membutuhkannya agar individu tersebut berkembang potensinya secara optimal, mampu mengatasi masalahnya, dan mampu menyesuaikan dirinya terhadap lingkungan yang selalu berubah (Willis, 2004).

Dari paparan di atas dapat dilihat bahwa konseling merupakan suatu proses komunikasi antara konselor dan konseli dalam suasana hubungan yang profesional dengan menerapkan teknik konseling, sehingga konselor dapat membantu konseli untuk mengatasi masalah yang sedang 
dihadapi dengan menggunakan kemampuan yang konseli miliki.

Beberapa ahli merumuskan tujuan konseling. Konseling biasanya ditujukan untuk membantu konseli menyelesaikan problem yang mengganggu mereka. Konseling juga dimaksudkan untuk membantu konseli mengembangkan beragam cara yang lebih positif untuk menyikapi hidup (Geldard \& Geldard, 2004). Sedangkan pendapat lain menyatakan tujuan dari konseling meliputi (a) menghasilkan perubahan pada perilaku yang memungkinkan konseli hidup lebih produktif dan memuaskan serta dapat menyesuaikan diri dengan baik di masyarakat; (b) pemeliharaan dan pencapaian kesehatan mental yang positif sebagai tujuan konseling; dan (c) pemecahan masalah yang dihadapi dalam hubungan konseling (Shertzer \& Stone, 1981).

Program konseling yang diselenggarakan di Sekolah Menengah atas dasar Permendikbud No 111 tahun 2014 pasal 2 salah satunya bertujuan untuk pengembangan potensi peserta didik secara optimal. Serta pasal 3 yang berbunyi layanan bimbingan dan konseling memiliki tujuan membantu konseli mencapai perkembangan optimal dan kemandirian secara utuh dalam aspek pribadi, belajar, sosial, dan karir. Siswa dapat mengalami permasalahanpermasalahan yang harus diselesaikan ketika berusaha untuk mengembangkan potensi secara optimal. Salah satu metode yang bisa dilaksanakan konselor untuk membantu konseli mengentaskan permasalahannya adalah konseling. Oleh karena itu, konselor perlu membuat program layanan konseling.

Program konseling yang diprogramkan konselor berpotensi memiliki permasalahan yang harus diselesaikan. Jika program konseling dilaksanakan konselor dengan baik, maka siswa dapat mengentaskan permasalahan dan mengembangkan potensinya secara optimal. Sebaliknya, jika program konseling dilaksanakan konselor tidak baik, maka siswa kesulitan mengentaskan permasalahan dan mengembangkan potensinya secara optimal.

Oleh sebab itu, perlu dilaksanakan evaluasi program konseling. Salah satu jenis evaluasi yang digunakan adalah evaluasi dengan menggunakan model discrepancy. Model ini dikembangkan oleh Malcom Provus. Tujuan dari penelitian evaluasi model discrepancy adalah mendeskripsikan kesenjangan antara realita kinerja konselor profesional dalam mengimplementasikan program bimbingan dan konseling di sekolah dengan standar.Selain itu, juga berorientasi pada suatu keputusan untuk membantu konselor dalam mengambil keputusan program konseling.

Beberapa penelitian menunjukkan bahwa evaluasi dengan menggunakan model discrepancy dapat mengukur kesenjangan antara performa program konseling dengan standar yang ditentukan. Penelitian yang dilakukan untuk mengevaluasi dengan model discrepancy untuk melihat kesenjangan antara performa program konseling di SMP kota Malang dengan standar yang ditentukan. Penelitian tersebut menunjukkan bahwa program konseling di SMP Kota Malang masih jauh dari standar (Saputra, 2015). Hasil penelitian tersebut juga merekomendasikan kepada konselor untuk memperbaiki kualitas pelaksanaan program konseling, sehingga memberikan pengaruh positif bagi siswa.

Penelitian selanjutnya, juga dilakukan untuk mengevaluasi dengan model discrepancy untuk melihat kesenjangan antara performa konseling individual dengan standar yang telah ditentukan. Penelitian tersebut menunjukkan bahwa program konseling individual di SMP Laboratorium Universitas Negeri Malang masih jauh dari standar. Secara rinci dipaparkan berikut ini: (a) $54,6 \%$ aspek kegiatan program konseling individual telah terlaksana dengan baik; (b) $9,1 \%$ aspek kegiatan program konseling individual hanya terlaksana sebagaian; dan (c) $36,4 \%$ program konseling individual tidak terlaksana sama sekali (Saputra, 2016a). Penelitian juga merekomendasikan kepada 
konselor untuk memperbaiki kualitas pelaksanaan program konseling, sehingga memberikan pengaruh positif bagi siswa.

Penelitian selanjutnya, penelitian evaluasi dengan model discrepancy untuk melihat kesenjangan program konseling kelompok dengan standar yang ditentukan. Berdasarkan analisis data evaluasi program konseling kelompok di SMP Laboratorium Universitas Negeri Malang masih jauh dari standar. Secara rinci dipaparkan berikut ini: (a) $51,1 \%$ aspek kegiatan program konseling kelompok telah terlaksana dengan baik; (b) $17,8 \%$ aspek kegiatan program konseling kelompok hanya terlaksana sebagaian; dan (c) $31,1 \%$ program konseling kelompok tidak terlaksana sama sekali (Saputra, 2016b).

Penelitian-penelitian terdahulu menunjukkan bahwa evaluasi program dengan model discrepancy adalah model yang perlu digunakan konselor. Hal ini dapat melihat kesenjangan antara performa atau implementasi program konseling dengan standar yang telah ditentukan. Hasil dari analisis data evaluasi model discrepancy dapat dijadikan landasan atau pedoman untuk mengambil keputusan terkait penyelenggaraan program konseling selanjutnya.

\section{KESIMPULAN}

Konseling adalah unsur penting dalam layanan bimbingan dan konseling. Pentingnya layanan konseling merupakan sebuah peluang dan sekaligus tantangan. Pentingnya program konseling individu ini, tentunya membutuhkan satu usaha untuk menilai keberhasilan program konseling. Salah satunya adalah dengan melaksanakan evaluasi dengan menggunakan model discrepancy. Evaluasi dengan model discrepancy dapat melihat kesenjangan antara performa atau implementasi program konseling dengan standar yang telah ditentukan.

\section{DAFTAR PUSTAKA}

Akhmadi, A. (2014). Peningkatan Kemampuan Konselor Profesional, Kajian Materi Diklat Jarak Jauh Guru Bimbingan Konseling.

Arikunto, S. (2009). Dasar-dasar Evaluasi Pendidikan (edisi revisi). Jakarta: Bumi Aksara.

Fitzpatrick, J. L., Sanders, J. R., \& Worthen, B. R. (2004). Program evaluation: Alternative approaches and practical guidelines. Boston: Pearson/Allyn and Bacon.

Geldard, K., \& Geldard, D. (2004). Membantu memecahkan masalah orang lain dengan teknik konseling. Yogyakarta: Pustaka Pelajar.

McKenna, C. (1981). Making evaluation manageable. Journal of Extention, 19(5), 1-14.

Mitchell, M. H., \& Gibson, R. L. (2011). Bimbingan dan konseling. Yogyakarta: Pustaka Pelajar.

Prayitno, \& Amti, E. (2004). Dasar-dasar bimbingan dan konseling. Jakarta: Rineka Cipta.

Rogers, C. R. (1995). On becoming a person: A therapist's view of psychotherapy (7th ed.). Boston: Houghton Mifflin Harcourt.

Rogers, Carl R. (1957). The necessary and sufficient conditions of therapeutic personality change. Journal of Consulting Psychology, 21(2), 95.

Rogers, Carl R. (1975). Empathic: An unappreciated way of being. The Counseling Psychologist, 5(2), 2-10.

Saputra, W. N. E. (2015). Evaluasi Program Konseling di SMP Kota Malang: Discrepancy Model. Jurnal Psikologi Pendidikan Dan Konseling: Jurnal Kajian Psikologi Pendidikan Dan Bimbingan Konseling, 1(2), 180-187.

Saputra, W. N. E. (2016a). Evaluasi Program Konseling Individu Di SMP Laboratorium Universitas Negeri Malang Dengan Model Discrepancy. Jurnal Fokus Konseling, 2(1), 1-10.

Saputra, W. N. E. (2016b). Evaluation of 
Group Counseling Program on SMP

Laboratorium Universitas Negeri

Malang: Discrepancy Model.

GUIDENA: Jurnal Ilmu Pendidikan,

Psikologi, Bimbingan Dan Konseling,

6(1), 11-17.

Shertzer, B., \& Stone, S. C. (1981).

Fundamental of Counseling. Boston:

Houghton Mifflin Company.

Sudjana, D. (2006). Evaluasi Program

Pendidikan Luar Sekolah: Untuk

Pendidikan Nonformal dan

Pengembangan Sumber Daya

Manusia. Bandung: Remaja

Rosdakarya.

Willis, S. S. (2004). Konseling individual

teori dan praktek. Bandung: Alfabeta. 